additional generating sets at a site already operational. The BN-600 fast breeder reactor at Beloyarsk, for example, was scheduled for completion in 1979 and it in fact went critical (with great publicity) in February 1980. The delays mentioned in Pravda refer to additional generating sets at the same site which, in the nature of things, receive less attention.

By blaming the suppliers and manufacturers of ancillary equipment, the Pravda leader-writer gives the impression that all would be well with the nuclear power programme if the manufacturers kept to their delivery dates. This, however, when the reactor for the third generating set at the Kursk power station went critical, almost three years late, the provincial Party is not the whole story. Last November,

Secretary, V. Ivanov, discussed the delay at some length in Pravda, on the page normally devoted to Party affairs.

Ivanov attributed the delay not only to a shortage of construction workers, followed by a sudden influx of 6,000 workers with consequent confusion and disorganized working, but also to basic difficulties with generating equipment. The Ministry of Power and Electrification, he said, had not finally solved one of the principal problems, the design of a standard production-model 1000-MW generating set. As a result, there had been, he said, a constant stream of every kind of correction and alteration between the site and the suppliers, so that the amount of installation work on the set was five times normal.

Vera Rich

Israel

\section{Backers for nuclear-free zone}

\section{Rehovot}

A I.EAI)IN come out against the building of nuclear weapons here, while a card-carrying dove has argued that Israel should openly join the nuclear weapons club. The hawk is Minister of Science and Development Yuval Ne'eman, who said recently in Jerusalem that it would not be in Israel's interests to base its defence on nuclear deterrence, because the nuclear balance of terror that exists between the superpowers would not work in the Middle East.

Professor Ne'eman is a renowned nuclear physicist and was for many years connected with Israel's defence establishment, so he presumably knows what he is talking about when he says that while Israel has a nuclear infrastructure, it "never crossed the threshold into the nuclear weapons club". He is convinced that a nuclear deterrent, which would not in any case be used unless the military threat against Israel were extremely grave, would not lessen its need to maintain conventional forces. Professor Ne'eman also points out that a nuclear device set off close to Israel's borders in order to destroy massed Arab armies would also destroy much of Israel.

The dove who favours nuclear weapons is Dr Shai Feldman of Tel Aviv University's Jaffee Centre for Strategic Studies. His controversial book, Israel's Nuclear Deterrence: $A$ Strategy for the 1980 s, bluntly calls on Israeli policymakers to make nuclear weapons the cornerstone of their country's defence. He speaks of an arsenal of 30 to 40 weapons in the 20 to 60 kiloton range.

Unlike Professor Ne'eman, Dr Feldman does not believe that contemporary Israel should embrace the West Bank and the Gaza Strip. This is consistent with his call for a defence policy based on nuclear deterrence because, in his view, Israel could withdraw to borders similar to those it held in 1967 , "declaring at the same time that any significant attempt by Arab armies to cross these borders would meet nuclear punishment". He believes that an openly nuclear-based defence policy would permit Israel to cut its huge expenditure on conventional weapons and on the maintenance of a large army, which places an increasing burden on the economy.

This view is disputed by many other observers, including Dr Yair Evron, a colleague of Feldman at Tel Aviv University. Evron declares that "no Israeli policymaker would be willing to rely exclusively on a nuclear deterrent".

Both Feldman and Evron doubt whether, in the long run, Israel will be able to prevent its enemies from acquiring nuclear weapons (as Prime Minister Begin said it would after the bombing of the Iraqi reactor in 1981). If they are right, what can Israel do to prevent a nuclear arms race, and perhaps nuclear war, in the Middle East?

Many foreign observers believe that all would be well if Israel would only agree to sign the Non-Proliferation Treaty (NPT), as have most other Middle Eastern states. But this view is not shared by most Israelis. A physicist at the Weizmann Institute, Shalheveth Freier, points out that Libya openly but vainly shopped for bombs before signing NPT, and, he adds, "it is to be doubted whether this switch in declaratory stance amounts to a change of intent".

What Freier, Ne'eman and others would like to see is an agreement among all the countries of the Middle East for the establishment of a nuclear weapons-free zone in this area, like the one set up in Latin America under the Treaty of Tlatelolco. For while NPT allows the country whose nuclear facilities are being inspected to determine who the inspectors will be and when they will come, the Tlatelolco Treaty calls for inspections at any time and by inspectors from the region itself.

Nechemia Meyers
Hungarian universities

\section{Market forces are felt}

HUNGARIAN academic science is fighting recent cuts in government budgets by going commercial. The first subsidiary company of a research institute has now been registered, and two Budapest universities have launched plans to admit students from outside the Socialist bloc who will pay their fees in hard currency.

Izinta, the new subsidiary of the Institute of Isotopes of the Hungarian Academy of Sciences, was created to circumvent a government decree reducing the number of people who may be employed by any research institute. The Institute of Isotopes, in addition to wide-ranging programmes of pure and applied research, has had since its foundation in 1959 a production department which supplies the Hungarian market with radiochemicals and irradiation services. Since 1961, the institute has exported its products and services through the state trading company Medimpex.

Hiving off the commercial side of the institute's activities to form Izinta was thus a fairly rational method of reducing staff. Thirty scientists and technicians have been transferred from the institute to the new company, which will return 25 to 40 per cent of its profit to the institute which, in return, guarantees the "productive, technological and economic" basis of Izinta.

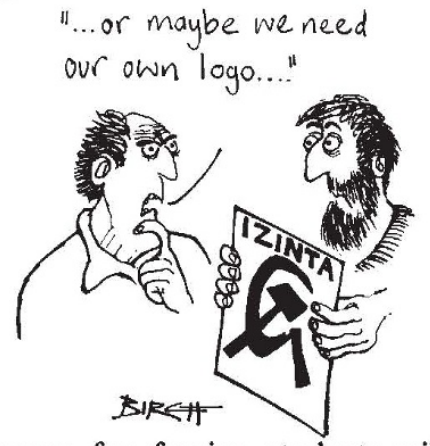

Courses for foreign students will be introduced at the Semmelweis Medical University (taught in German) and at the Budapest Technical University, where the languages of tuition will include English.

According to Dr Miklos Ivanyi, vicerector of the Technical University, a "considerable proportion" of the hard currency thus earned will remain at the disposal of the university, while lecturers teaching the courses may be able to draw part of their salaries in dollars. Since a shortage of hard currency for journal subscriptions, laboratory equipment and foreign travel is a growing problem of Hungarian academic life, other Hungarian universities may well decide to follow suit. Fees, said Dr Ivanyi, have not yet been decided, but will probably be significantly less than at similar establishments outside Hungary.

Vera Rich 